Subscriber access provided by Université de Liège

\title{
Article
}

\section{Factors influencing the bioaccumulation of persistent organic pollutants in food webs of the Scheldt estuary}

Evy Van Ael, Adrian Covaci, Krishna Das, Gilles Lepoint, Ronny Blust, and Lieven Bervoets

Environ. Sci. Technol., Just Accepted Manuscript • DOI: 10.1021/es400307s • Publication Date (Web): 05 Sep 2013

Downloaded from http://pubs.acs.org on September 13, 2013

\section{Just Accepted}

"Just Accepted" manuscripts have been peer-reviewed and accepted for publication. They are posted online prior to technical editing, formatting for publication and author proofing. The American Chemical Society provides "Just Accepted" as a free service to the research community to expedite the dissemination of scientific material as soon as possible after acceptance. "Just Accepted" manuscripts appear in full in PDF format accompanied by an HTML abstract. "Just Accepted" manuscripts have been fully peer reviewed, but should not be considered the official version of record. They are accessible to all readers and citable by the Digital Object Identifier (DOI®). "Just Accepted" is an optional service offered to authors. Therefore, the "Just Accepted" Web site may not include all articles that will be published in the journal. After a manuscript is technically edited and formatted, it will be removed from the "Just Accepted" Web site and published as an ASAP article. Note that technical editing may introduce minor changes to the manuscript text and/or graphics which could affect content, and all legal disclaimers and ethical guidelines that apply to the journal pertain. ACS cannot be held responsible for errors or consequences arising from the use of information contained in these "Just Accepted" manuscripts. 
1 Factors influencing the bioaccumulation of persistent organic

2 pollutants in food webs of the Scheldt estuary

3

4 Evy Van $\mathrm{Ael}^{1 *}$, Adrian Covaci ${ }^{2}, \mathrm{Krishna} \mathrm{Das}^{3}$, Gilles Lepoint $^{3}$, Ronny Blust ${ }^{1}$ and Lieven

5 Bervoets $^{1}$

6

$7{ }^{1}$ Laboratory of Systemic Physiological and Ecotoxicological Research, Department of

8 Biology, University of Antwerp, Groenenborgerlaan 171, 2020 Antwerp, Belgium

$9 \quad{ }^{2}$ Toxicological Center, University of Antwerp, Universiteitsplein 1, 2610 Wilrijk, Belgium

$10{ }^{3}$ MARE Centre, Laboratory of Oceanology, Liège University, 4000 Sart Tilman, Belgium

11

12 * Corresponding author: Laboratory of Systemic Physiological and Ecotoxicological

13 Research, Department of Biology, University of Antwerp, Groenenborgerlaan 171, 2020

14 Antwerp, Belgium. Fax: +32-(0)3-265.34.97 E-mail: evy.vanael@ua.ac.be

15

16 


\section{Abstract}

18 Concentrations of several persistent organic pollutants (POPs: PCBs, PBDEs, OCPs) in 19 aquatic species from the Scheldt estuary were related with factors (body size, lipids, trophic 20 position) possibly influencing their bioaccumulation. Stable nitrogen isotope ratios $\left(\delta^{15} \mathrm{~N}\right)$ 21 were used as a measure for trophic position. A decreasing trend in POP levels towards the sea 22 was observed. For POP concentrations in sediments, this trend could be attributed to a 23 dilution effect from mixing with seawater. However, concentrations in biota more 24 downstream were higher than expected after taking into account the dilution effect, possibly 25 due to differences in bioavailability. Tissue concentrations were correlated with the lipid 26 content in biota, but not with body size. Biomagnification was only significant for some PCB 27 congeners and $p, p^{\prime}$-DDE at the most marine sampling location (Terneuzen, L1) and for $p, p^{\prime}$ 28 DDD and BDE 100 at the second sampling location (Bath, L2). A significant decreasing 29 relationship was found for $\gamma-\mathrm{HCH}$ concentrations with increasing $\delta^{15} \mathrm{~N}$ at Terneuzen. For 30 Antwerpen (L3), no significant relationships were detected. TMFs ranged from 0.64 for $\gamma$ $31 \mathrm{HCH}$ up to 1.60 for PCB 194. These results suggest that biomagnification was more important 32 in the marine part of the estuary, although the presence of multiple carbon sources at the 33 freshwater side might have led to an underestimation of the influence of trophic position.

\section{Keywords}

36 Persistent organic pollutants; Polychlorinated biphenyls (PCBs); Polybrominated diphenyl 37 ethers (PBDEs); Stable carbon and nitrogen isotopes; Biomagnification; Scheldt estuary 


\section{$38 \quad$ Introduction}

Intensive industrial and agricultural activities have caused the worldwide introduction of organic chemicals in the aquatic environment. Man-made chemicals, such as polychlorinated biphenyls (PCBs), polybrominated diphenyl ethers (PBDEs) and organochlorine pesticides (OCPs), can persist for many years in these environments, hence forming a possible health threat for wildlife and humans through bioaccumulation ${ }^{1-3}$. The bioaccumulation of persistent organic pollutants (POPs), which mostly have a lipophilic character, into aquatic biota is believed to be mainly driven by two processes. The first process is the direct partitioning of chemicals between the organism's body and the abiotic environment, also called bioconcentration. The second process is dietary uptake ${ }^{4}$. However, for lipophilic POPs $\left(\log K_{\mathrm{ow}}>5\right)$ bioconcentration is considered to be of less importance for most fish when compared to dietary uptake ${ }^{5}$. If the chemical concentration in a consumer exceeds the concentration in his diet, and if the absorption rate exceeds the elimination from the body through biotransformation, growth and reproductive loss, biomagnification occurs. In this case, the POP level in an aquatic species will be influenced by its trophic position in the local food web. Consequently, top predators tend to contain the highest body burdens of pollutants and may also suffer the highest risk for adverse health effects ${ }^{6}$.

To understand the importance of trophic transfer in relation to the fate of pollutants in the food web and quantify the extent of biomagnification, the first step is to determine the trophic positions of the species in the food web. A frequently used method for this is the analysis of stable isotope ratios, as the isotopic signature of an animal reflects its assimilated $\operatorname{diet}^{7,8}$. By measuring stable isotope ratios as well as the pollution levels in several species, it is possible to identify and quantify biomagnification within a food web ${ }^{9}$.

The present study was conducted in the Scheldt estuary (the Netherlands - Belgium). The river Scheldt is a lowland-river which has its source in St. Quentin (France), flows 
63 through Belgium and flows into the North Sea in Vlissingen (the Netherlands). The river has a 64 total length of $355 \mathrm{~km}$ and the tidal effects reach $160 \mathrm{~km}$ upstream, until Ghent ${ }^{10}$. With a total 65 catchment area of $22000 \mathrm{~km}^{2}$, the river receives water from dense populated and 66 industrialized areas, enriching the estuary with nutrients and pollutants, including trace 67 metals $^{11}$ and POPs ${ }^{3,12}$, making the Scheldt one of the most polluted estuaries in Europe. 68 Nonetheless, the estuary is of great ecological value, for example because of its function as 69 nursery room for demersal fish species, as breeding area of the harbor seal (Phoca vitulina) ${ }^{13}$, 70 and because of the international importance for seabird conservation ${ }^{14}$. For this reason it is 71 essential to establish the fate of man-made chemicals in the estuary and their possible effects 72 in the food webs. In this paper, concentrations of POPs in different aquatic species from the Scheldt 74 estuary were measured and related with their stable isotope ratios, as a measure for trophic 75 position, to see whether POPs are biomagnified through the food web in this estuary. The 76 study was conducted at three different locations along the salinity gradient to compare the fate 77 of POPs in freshwater versus saltwater conditions. Tissue POP concentrations were also 78 linked with other factors (body size, lipid content), possibly influencing the bioaccumulation 79 of POPs. 


\section{Material and Methods}

82

\subsection{Sample collection}

In June 2011, samples were collected at three locations along the Scheldt Estuary (Fig. 1): Terneuzen $\left(51^{\circ} 35^{\prime} \mathrm{N} 3^{\circ} 88^{\prime} \mathrm{E}\right)$, Bath (the Netherlands, $\left.51^{\circ} 40^{\prime} \mathrm{N} 4^{\circ} 21^{\prime} \mathrm{E}\right)$ and Antwerpen (Belgium, $\left.51^{\circ} 23^{\prime} \mathrm{N} 4^{\circ} 39^{\prime} \mathrm{E}\right)$. Fish, crab and shrimp species were collected by means of fyke fishing (INBO, Research Institute for Nature and Forest) and trawl fishing with the vessel Zeeleeuw (VLIZ, Flanders Marine Institute). Other invertebrates were sampled on the shore by hand at low tide. Filamentous algae were collected from rocks. An overview of the collected species is given in Table 1. More detailed data on the lipid content, length and weight of the collected samples is provided in Table SI-1 of the Supporting Information (SI). Suspended particulate matter (SPM) was collected by filtration of surface water with a vacuum pump over glass fiber filters (VWR International, pore size $0.7 \mu \mathrm{m}$ ). Because of limited sample size, no POP analyses could be performed on SPM samples. The top layer (10 $\mathrm{cm}$ ) of the surface sediment was sampled manually from the shores at low tide. At each location, three replicates were taken. TOC (total organic carbon) was determined through Loss on Ignition (LOI). To this, the sediment subsamples were incinerated at $550{ }^{\circ} \mathrm{C}$ for $4 \mathrm{~h}$ and weight loss was determined ${ }^{15}$.

8 Before freezing and dissection, the organisms were kept for depuration in filtered locally collected river water $(0.2 \mu \mathrm{m})$ for $24 \mathrm{~h}$. A part of the caudal musculature of the fish was sampled to perform stable isotopes and POP analyses. For smaller fishes, crabs and shrimps, the whole musculature was homogenized for analysis. Soft tissues of other invertebrates were analyzed as a whole. For POP analysis, tissues from shrimps, mollusks and bristle worms were pooled to get an adequate sample size. Stable isotopes in shrimps, mollusks and bristle worms were determined in individual samples from the same area, which 
105 were not analyzed for POPs. Filamentous algae were rinsed to remove sand and organisms.

106 All samples were frozen $\left(-20^{\circ} \mathrm{C}\right)$ until analysis.

107

108

\subsection{POP analysis}

The following POPs were targeted for analysis in all samples: 33 PCB congeners

110 (IUPAC numbers: CB 18, 28, 44, 49, 52, 87, 95, 99, 101, 105, 110, 118, 128, 138, 146, 149,

$111151,153,156,170,171,172,174,177,180,183,187,194,195,199,205,206,209), 7$

112 PBDEs (IUPAC numbers: BDE 28, 47, 99, 100, 153, 154, 183), DDXs (o,p'-DDD, p,p'-

113 DDD, o,p'-DDE, $p, p^{\prime}$-DDE, $o, p^{\prime}$-DDT, $p, p^{\prime}$ 'DDT), chlordanes (TC, CC, TN, OxC), HCHs

$114(\alpha-, \beta-, \gamma$-hexachlorocyclohexane) and HCB (hexachlorobenzene). PBDE 209 was measured

115 only in the sediment samples due to low expected concentrations in biota relative to the rather

116 high method $\mathrm{LOQ}^{3,16}$. A detailed description of the methods used for POP analysis and

117 quality control is described in Van Ael et al. ${ }^{3}$ and is provided as SI.

2.3 Stable isotope analysis

120 To indicate the trophic position of the collected species, carbon and nitrogen stable

121 isotope ratios $\left(\delta^{13} \mathrm{C}\right.$ and $\left.\delta^{15} \mathrm{~N}\right)$ were measured. For this, muscle tissues (fish, crabs, shrimps) or

122 whole soft body (mollusks, bristle worms, Chaetogammarus marinus) tissues were freeze

123 dried and ground to a powder with mortar and pestle. From fish tissues with a high lipid

124 content, lipids were extracted by rinsing the samples with chloroform:methanol $(2: 1, \mathrm{v} / \mathrm{v})$.

125 SPM samples, that potentially contained carbonates, were acidified by placing them during

$12624 \mathrm{~h}$ under a glass jar with fuming $\mathrm{HCl}(37 \%)$, to remove calcareous material ${ }^{8}$. Samples were

127 measured before and after acidification or removal of lipids. Stable isotope ratios were

128 determined using a mass spectrometer (VG Optima, Isoprime, UK) equipped with an

129 elemental analyzer (Carlo Erba, Italy) for combustion and automated analysis. Carbon and 
130 nitrogen isotope ratios were expressed as $\delta$ values (\%o) relative to the Vienna PeeDee

131 Belemnite (vPDB) standard and to atmospheric $\mathrm{N}_{2}$ respectively. IAEA-N1 $\left(\delta^{15} \mathrm{~N}=0.4 \pm\right.$ $1320.2 \%$ ) and IAEA C-6 $\left(\delta^{13} \mathrm{C}=-10.8 \pm 0.2 \%\right.$ ) were used as reference materials. Standard 133 deviations for multi-batch replicated measurements $(\mathrm{N}=22)$ of one fish muscle sample were $134 \pm 0.19$ and $\pm 0.25 \%$ for $\delta^{15} \mathrm{~N}$ and $\delta^{13} \mathrm{C}$, respectively.

\subsection{Statistical analysis}

POP concentrations below the LOQ were substituted by a value of LOQ*f (detection frequency). After testing the normality and homogeneity of variances, concentrations were log-transformed where necessary. Differences between locations were detected by using Oneway ANOVA with Tukey test or Student's t-test. The level of statistical significance was set at $\mathrm{p}<0.05$. Pearson correlation was applied to determine the influence of lipid content and body size (length and weight) on the bioaccumulation of POPs.

The dilution effect of mixing with seawater, which may cause lower sediment and biota POP concentrations more downstream in the estuary, was tested by normalizing the POP concentrations for salinity. Therefore, the POP concentrations were multiplied by the ratio of salinity at (Site X/Anwerpen). Salinity values used: Terneuzen, 27.3; Bath, 15.6; Antwerpen, 3.4. Ratios used: (Terneuzen/Antwerpen) $=8.1 ; \quad$ (Bath/Antwerpen) = 4.7; $($ Antwerpen/Antwerpen $)=1$. Salinity values are year averages from a monitoring database from Rijkswaterstaat, a part of the Dutch Ministry of Infrastructure and the Environment, and 150 from the Flemish Environment Agency (VMM). using Student's t-test. 
155 of trophic levels (TLs) has been used in several studies to indicate trophic magnification. To 156 derive the TL from $\delta^{15} \mathrm{~N}$ values the following equation is often used ${ }^{17}$ :

$$
\mathrm{TL}_{\text {(consumer) }}=2+\left(\delta^{15} \mathrm{~N}_{\text {consumer }}-\delta^{15} \mathrm{~N}_{\text {primary consumer }}\right) / \Delta \delta^{15} \mathrm{~N}
$$

158 where $\Delta \delta^{15} \mathrm{~N}$ is the trophic enrichment factor or the shift in $\delta^{15} \mathrm{~N}$ between consecutive TLs ${ }^{17}$.

159 Trophic magnification factors (TMFs) are than calculated from the slope of the regression

160 between log-transformed concentrations of pollutants and the trophic levels ${ }^{18}$. However, the

161 trophic enrichment factor ranges between 3\%o and 5\%o and can be variable, depending on

162 species, diet, tissue and physiology ${ }^{19}, 20$, making it questionable to apply a fixed value for

$163 \Delta \delta^{15} \mathrm{~N}$. For this reason TLs were not calculated in this study ${ }^{21}$. TMFs are calculated as the

164 antilog with base 10 of the slope from the regression between log-transformed concentrations

165 of pollutants and $\delta^{15} \mathrm{~N}$ values ${ }^{22}$.

166 Multiple regressions models were constructed to analyse the combined effect of lipid 167 content and $\delta^{15} \mathrm{~N}$.

168 Statistical analyses were performed using GraphPad Prism 6.00 (GraphPad Software, 169 Inc). 


\section{Results and discussion}

172

173

174

175

176

177

178

180

181

182

183

184

\subsection{POP concentrations}

Median (+ range) POP concentrations and lipid content in biota and sediment samples are reported in Table 1. Average TOC content $( \pm \mathrm{SD})$ in the sediment measured $2.7 \pm 1.5 \%$, $2.5 \pm 1.1 \%$ and $4.7 \pm 2.5 \%$ for Terneuzen, Bath and Antwerpen respectively. Sediment PCB concentrations were low, ranging from 1.8 up to $58.7 \mathrm{ng} / \mathrm{g} \mathrm{dw}$. PCB levels in biota samples were highest in European eel (Anguilla anguilla), ranging from 846 up to $2190 \mathrm{ng} / \mathrm{g}$ ww. Lowest PCB concentrations were found in common periwinkle (Littorina littorea) (from 17.6 up to $28.0 \mathrm{ng} / \mathrm{g} \mathrm{ww}$ ). Median PCB concentrations in Baltic tellin (Macoma balthica), European sprat (Sprattus sprattus) and European eel exceeded the maximum limit for the sum of the 6 indicator PCBs ( $75 \mathrm{ng} / \mathrm{g} \mathrm{ww}$; indicated in bold), as set by European legislation ${ }^{23}$. Concentrations in European eel also exceeded the consumption limit of $300 \mathrm{ng} / \mathrm{g}$ for muscle meat of wild caught eel $^{24}$. PCB 153 was the most dominant congener in all species $(12-28 \%$ of $\sum$ PCBs), followed by PCB 138 and 149. Only in filamentous algae, PCB 149 was most abundant (11\%). PCB 18, 205, 206 and 209 were not frequently detected in all samples.

From the PBDE congeners, PBDE 209 was dominant in the sediment (99.7\%), while in the tissues, BDE 47 was most abundant (32-69\%, with PBDE 209 not measured in tissues). Total PBDE concentrations in the sediment ranged from 1.70 up to $575 \mathrm{ng} / \mathrm{g} \mathrm{dw}$. Median tissue PBDE concentrations were lowest in brown shrimp (Crangon crangon) and common periwinkle (0.01 ng/g ww) and highest in European eel (8.76 ng/g ww).

Chlordanes were not detected in the sediment and only in low concentrations in biota samples: medians from below detection limit up to $5.67 \mathrm{ng} / \mathrm{g}$ ww in European eel (Table 1). Trans-chlordane was the most detected chlordane, although in European eel, oxychlordane reached the highest concentrations. $p, p$ '-DDE was the most detectable DDT congener. $\sum$ DDT ranged from $0.56 \mathrm{ng} / \mathrm{g}$ ww in brown shrimp up to $49.3 \mathrm{ng} / \mathrm{g}$ ww in European eel. 
The contaminant levels measured in the present study were relatively high compared

197 to studies from other regions. PCB concentrations in European eel were higher than

198 concentrations detected in eels from the Garigliano river in Italy (119.7-2156 ng 7 ICES

199 PCB/g lw; present study: 3851-5670 ng 7 ICES PCB/g lw) $)^{25}$ and from five Irish rivers (13.7-

200197 ng 7 ICES PCB/g lw $)^{26}$. Detected PCB levels in European eel were within the ranges

201 previously measured in Flanders (Belgium) by Belpaire et al..$^{27}$ (11.4-7753 ng 7 ICES PCB/ng

202 ww). In the present study however, higher average concentrations were measured in eels from

203 Antwerpen (Belpaire et al., 2011: 513.4 ng 7 ICES PCB/g ww; present study: average 814.5

204 ng 7 ICES PCB/g ww). A French study from Bragigand et al. ${ }^{28}$ showed lower PBDE levels in

205 European eels from the Loire estuary (0.13-0.57 ng BDE 47/g ww; present study: 4.40-11.0

$206 \mathrm{ng} \mathrm{BDE} \mathrm{47/g} \mathrm{ww)} \mathrm{and} \mathrm{comparable} \mathrm{levels} \mathrm{in} \mathrm{eels} \mathrm{from} \mathrm{the} \mathrm{Seine} \mathrm{estuary} \mathrm{(2.67-7.84} \mathrm{ng} \mathrm{BDE}$

$20747 / \mathrm{g} \mathrm{ww})$.

208 PCB concentrations in European sprat from the Polish Baltic Sea were five times

209 lower (average 20.8 ng 6 ICES PCBs/g ww; present study: average 102 ng 6 ICES PCBs/g

$210 \mathrm{ww})^{29}$. PBDE concentrations in pike-perch (Sander lucioperca) from the present study were

211 higher than in pike-perch from the Baltic Sea (average $0.57 \mathrm{ng} / \mathrm{g}$ ww for $15 \mathrm{PBDE}$ congeners;

212 present study: average $1.88 \mathrm{ng} / \mathrm{g}$ ww for $7 \mathrm{PBDE}$ congeners) ${ }^{30}$. Ragworm (Nereis

213 diversicolor) contained higher PBDE concentrations than ragworms from the Loire and the

214 Seine estuary (0.03-0.12 ng BDE47/g ww; present study 0.15-0.62 ng BDE 47/g ww $)^{28}$; and

215 Nereis virens from the St. Lawrence estuary, Canada (average $0.18 \mathrm{ng}$ BDE 47/g ww) ${ }^{31}$.

216 PBDE levels detected in brown shrimp were lower than previously reported for the North Sea

217 by Boon et al. ${ }^{32}$ (average of $37 \mathrm{ng} \mathrm{BDE} \mathrm{47/g} \mathrm{lw)} \mathrm{and} \mathrm{for} \mathrm{the} \mathrm{Scheldt} \mathrm{by} \mathrm{Voorspoels} \mathrm{et} \mathrm{al.}{ }^{16}$

218 (0.2-8.3 ng $\sum 6$ PBDE/g ww). Van Leeuwen and de Boer measured comparable levels of

219 PBDEs in sole, brown shrimp, blue mussels and pike-perch in Dutch rivers and lakes.

220 However, concentrations in European eel (0.4-81 ng BDE47/g ww; present study: 4.4-11 ng 
BDE47/g ww) and European flounder (4.4-11 ng BDE47/g ww; present study: 0.09-2.17 ng

222

223

224

225

226

227

BDE47/g ww) were higher ${ }^{33}$.

Similar concentrations were measured in a previous study in organisms from the same system (European flounder: median 46.1 ng 6 ICES PCBs/g ww; present study: 42.5 ng 6 ICES PCBs/g ww; Common sole: median 17.2 ng 6 ICES PCBs/g ww; present study: 22.2 ng 6 ICES PCBs/g ww). ${ }^{3}$

The concentration of each individual contaminant was highest in European eel. Eel species are known for their ability to accumulate lipophilic substances ${ }^{2}$. They are carnivorous predators and compared to other fish species, they show very high lipid values (average of $18.6 \%$ in the present study).

The tissue concentrations (ww) of several POPs in the aquatic biota were significantly correlated with their lipid content. Correlations were very strong for biota collected in Antwerpen $(\mathrm{p}<0.0008)$. From the 55 analyzed POPs, 50 compounds showed a correlation with the lipid content (with $\mathrm{r}^{2}>0.2$ ). This data set included the European eel, which is known for its high lipid content. When eels were excluded from the data set, POP concentrations and lipid content were less correlated $(\mathrm{p}<0.0391,14$ significant correlations $)$. In samples from Bath, tissue concentrations of 22 POPs were significantly correlated with the lipid content $(p<0.0006)$. In Terneuzen, 29 POP congeners showed significant correlations between tissue concentrations and lipid content $(\mathrm{p}<0.0045)$. Table SI-2 lists all significant correlations ( $\mathrm{p}$ and $\left.r^{2}\right)$.

The individual length and weight of fish and crabs have been plotted against tissue concentrations of POPs. Positive significant relationships were found for most compounds (ww) in European flounder near Antwerpen $(0.002<\mathrm{p}<0.033)$ and for some PCB congeners (ww) in smelt (Osmerus eperlanus) from Bath $(0.014<\mathrm{p}<0.033)$. For the other species no significant correlations were detected. Increasing POP concentrations with increasing body 
246 size were found for PCBs and PBDEs in salmon (Oncorhynchus sp. $)^{34}$ and for PBDEs in 247 striped bass (Morone saxstilis) and catfish (Pilodictus olivaris and Ictalurus punctatus) ${ }^{35}$. As 248 body size increases, the elimination rates for lipophilic compounds via direct partitioning 249 through the water decreases because of a reduced exchange surface ${ }^{5,36}$. However, in the 250 present study, few correlations were significant. The body size has influence on the 251 bioaccumulation process, but the effect appears to be overwhelmed by other factors, like 252 trophic position and lipid content.

253 Higher POP concentrations were generally found more upstream from the estuary. 254 Although this trend was not statistically significant in sediment samples, a significant 255 difference was found in the tissues of European flounder (Platichthys flesus) $(0.007 \leq \mathrm{p} \leq$ 256 0.353), shore crab (Carcinus maenas) (for PCBs, $0.002 \leq \mathrm{p} \leq 0.017$ ) and bristle worm 257 (Polychaeta; Terneuzen: Arenicola marina; Bath and Antwerpen: Nereis diversicolor) (0.035 $258 \leq \mathrm{p} \leq 0.047$ ) (Fig. 2). This indicates that the POP levels are higher more upstream of the 259 estuary, probably caused by the vicinity of the city of Antwerpen, which is highly 260 industrialized and urbanized. Furthermore, the Scheldt receives waste waters from other large 261 cities like Brussels. This observation has been described before in other studies ${ }^{3,16,37}$. More 262 downstream in the estuary, lower environmental pollution levels could be attributed to a 263 dilution effect, because of a wider riverbed and the increasing mixing with seawater. Since the 264 salinity can be used as a measure for the dilution with seawater, it can be tested if the dilution 265 effect is responsible for the decreasing trend in POP levels. If POP concentrations in 266 sediments are normalized for salinity, the decreasing trend towards the North Sea gets 267 minimalized and the normalized concentrations get more or less constant (Fig. 2). This means 268 that the dilution of the river water explains lower POP concentrations in the sediments 269 towards the sea. However, normalizing the POP concentrations in bristle worm and European 270 flounder for salinity (Fig. 2) does not have the same effect. Biota from Terneuzen (L1) and 
271 Bath (L2) contain higher POP levels than expected from the dilution gradient, in contrast to 272 concentrations in the sediment. When performing the same normalization on lipid weight POP 273 concentrations, the same results were obtained. Possible POP sources more downstream in the 274 estuary such as industrial factories in Terneuzen or the Ghent-Terneuzen canal, could cause 275 local higher POP concentrations. However, these are not reflected in the sediment POP 276 concentrations. For European flounder, possible migration from one location in the estuary to 277 another must be taken into account. Nevertheless, a significant difference in tissue 278 concentrations of POPs from the different locations was observed. The differences in 279 bioaccumulation along the salinity gradient may be caused by variation in the bioavailability. 280 Moreover, this also implies that sediment concentrations are poor predictors of 281 bioaccumulation, because pollutant levels were much higher in the downstream parts of the 282 estuary than expected on the basis of the sediment concentrations.

\subsection{Isotopic compositions}

The isotopic compositions of the samples collected at the three sampling locations are reported in Figure 3. With an average value of $-26.4 \%$, $\delta^{13} \mathrm{C}$ values for SPM samples were

287 comparable with previously reported values for the Scheldt estuary ${ }^{38,} 39$. SPM from the 288 riverine part of the Scheldt is more ${ }^{13} \mathrm{C}$ depleted $(-27.7 \%$ ) than SPM from the marine side ($28925.3 \%$ ), indicating the input of riverine and terrestrial organic matter in the upper estuary ${ }^{39}$. 290 Consumers $\delta^{13} \mathrm{C}$ values ranged from $-27.6 \%$ for pike-perch in Antwerpen up to $-17.3 \%$ o for 291 common periwinkle in Terneuzen. Freshwater species, such as pike-perch, had slightly more

$292{ }^{13}$ C-depleted values when compared to marine species. Species at the bottom of the food web, 293 such as Oligochaeta and Baltic tellin $(\mathrm{p}=0.0002)$ had less depleted $\delta^{13} \mathrm{C}$ values when 294 sampled in Terneuzen (L1) compared with two other locations (Bath, L2 and Antwerpen, L3). 295 The available carbon sources in Terneuzen were probably mainly marine sources, which are 
296 typically less $\delta^{13} \mathrm{C}$ depleted than those of freshwater ${ }^{8,40}$, while the two other locations receive 297 more terrestrial and riverine input.

298 The large variation in $\delta^{13} \mathrm{C}$ values in the present study indicates consumers are feeding 299 on different carbon sources and may also be part of different food webs. For this reason, $\delta^{15} \mathrm{~N}$ 300 values are site-specific and were used as an overall indication of site-specific trophic position.

301 Mean consumer $\delta^{15} \mathrm{~N}$ values ranged from $13.7 \%$ for mud shrimp (Corophium 302 volutator) in Terneuzen (L1) to 21.6\% for ragworm in Antwerpen (L3), although these values 303 for ragworm were exceptionally high. In general, invertebrates such as the bivalves blue 304 mussel (Mytilus edulis) and Baltic tellin showed the lowest $\delta^{15} \mathrm{~N}$ values. Highest $\delta^{15} \mathrm{~N}$ values 305 were detected in carnivorous fish. Filamentous algae showed relatively high $\delta^{15} \mathrm{~N}$ values, 306 especially the samples collected at Terneuzen (L1).

\subsection{Influence of trophic position on bioaccumulation}

Several PCB congeners and $p, p^{\prime}$-DDE showed a significant increase in log310 transformed lipid weight concentrations with increasing $\delta^{15} \mathrm{~N}$ values (Table 2, Figure 4) for

311 the samples collected at Terneuzen (L1), indicating a positive relationship between pollution

312 level and trophic level. A significant decreasing trend was found for $\mathrm{\gamma}-\mathrm{HCH}$ concentrations

313 with increasing $\delta^{15} \mathrm{~N}$. In Bath (L2), significant relationships were only found for $p$, $p$ '-DDD 314 and BDE 100. For Antwerpen (L3), no significant relationships were detected. TMFs were 315 higher than 1, except for the TMF for $\gamma-\mathrm{HCH}$, indicating biomagnification in the Scheldt 316 estuary. TMFs ranged from 0.64 for $\gamma-\mathrm{HCH}$ up to 1.60 for PCB 194 (Table 2).

317 As mentioned above, the large variation in $\delta^{13} \mathrm{C}$ values in the present study indicates 318 consumers are feeding on different carbon sources and may be part of different food webs.

319 However, the significant relationship observed still suggest biomagnification of the selected 
320 compounds. This could mean that the $\delta^{15} \mathrm{~N}$ values of the baseline are similar between sources 321 at one site, making the delta $15 \mathrm{~N}$ values an overall indication of site-specific trophic position.

322 The biomagnification of PCBs has been described before in food webs at various 323 locations, such as a marine food web in Norway ${ }^{41}$, in fish of the sub-alpine Como Lake in 324 Italy $^{42}$, in arctic food webs ${ }^{41,43}$ and in a freshwater food web from China ${ }^{44}$. The TMFs found 325 in the present study for PCBs are lower than TMFs found in the Iroise Sea (Western Brittany) 326 and the Seine Bay $(1.9-17.3)^{45}$, Congo River Basin $(1.72-2.93)^{9}$, the Northwater Polynya 327 marine food web $(1.7-10.7)^{46}$, lakes in Canada and the north eastern US (1.3-8.0) ${ }^{47}$ and from a 328 freshwater food web from South China $(0.75-5.10)^{44}$.

329 In the present study, biomagnification of PCBs was linked with the degree of 330 chlorination of the PCB congeners. Regressions were only significant for hexa- to octa-PCBs, 331 which also possess higher $\log \mathrm{K}_{\mathrm{ow}}$ than lower chlorinated congeners. However, this statement 332 probably holds only for non-metabolizable PCB congeners. The same trend was also reported 333 by Skarphedinsdottir et al. ${ }^{48}$ in a food web near the coast of Iceland. Yu et al. ${ }^{49}$ described a 334 parabolic relationship between the TMFs of PCBs for freshwater fish and the $\log \mathrm{K}_{\mathrm{ow}}$, with 335 largest TMFs at $\log \mathrm{K}_{\mathrm{ow}}$ of 6.89. In the present study however, the greatest TMF was found 336 for PCB 194, which has a $\log \mathrm{K}_{\mathrm{ow}}$ greater than $6.89\left(\log \mathrm{K}_{\mathrm{ow}}=7.8\right)$. PCBs were clearly more 337 biomagnified than PBDEs, which only showed a significant relationship with $\delta^{15} \mathrm{~N}$ in case of 338 PBDE 100, with a TMF of 1.17. The lower biomagnification potential of PBDEs was 339 previously reported ${ }^{50,51}$. Although Kelly et al. ${ }^{51}$ demonstrated the biomagnification of BDE 34047 in a marine food web, they found that the TMF for BDE 47 was much lower than the 341 TMFs of comparable PCBs.

342 No biomagnification was found for $\mathrm{HCHs}$. For $\gamma-\mathrm{HCH}$, a significant decreasing 343 relationship of concentration with increasing $\delta^{15} \mathrm{~N}$ values was observed (Table 2). When 344 compared to PCBs or DDTs, HCHs have a lower $\log \mathrm{K}_{\mathrm{ow}}$, indicating that they may have a 
345 lower bioaccumulation potential. This limited bioaccumulation of HCHs has been

346 documented in several studies ${ }^{21,41}$. Other authors have stated before that species ecology has a

347 minor influence on the bioaccumulation of substances with $\log \mathrm{K}_{\mathrm{ow}}<5^{4,52}$. Moreover, some

348 fish species, such as shorthorn sculpin (Myoxocephalus scorpius), have the ability to rapidly

349 eliminate $\mathrm{\gamma}-\mathrm{HCH}$ after oral exposure ${ }^{53}$, which can result in lower concentrations in their 350 predators.

351 Significant multiple regressions models were constructed for the combined effect of 352 lipid content and $\delta^{15} \mathrm{~N}$. For PCB 153 and $p, p^{\prime}$-DDE at Terneuzen, the regression resulted in 353 the following equations: [PCB153] $=2.91 \times \delta^{15} \mathrm{~N}+11.5 \times$ Lipid with $\mathrm{p}<0.0001$ and $\mathrm{R}^{2}=0.55$; $354\left[p, p^{\prime}-\mathrm{DDE}\right]=0.55 \times \delta^{15} \mathrm{~N}+1.99 \times$ Lipid with $\mathrm{p}<0.0001$ and $\mathrm{R}^{2}=0.58$. For $\mathrm{\gamma}-\mathrm{HCH}$ at 355 Terneuzen, no significant model was found. For $p, p$ '-DDD and BDE100 at Bath, the 356 following equations were obtained: $\left[p, p^{\prime}-\mathrm{DDD}\right]=0.063 \times \delta^{15} \mathrm{~N}+1.16 \times$ Lipid with $\mathrm{p}<0.0001$ 357 and $\mathrm{R}^{2}=0.75 ;[\mathrm{BDE} 100]=0.013 \times \delta^{15} \mathrm{~N}+0.11 \times$ Lipid with $\mathrm{p}<0.0001$ and $\mathrm{R}^{2}=0.42$.

358 The results of this study indicate that biomagnification is more pronounced in the 359 marine part of the estuary, as stronger relationships between POP level and $\delta^{15} \mathrm{~N}$ values were 360 found closest to the sea. At the most downstream sampling location (L1, Terneuzen), the 361 available food sources will be mainly from marine origin, in contrast with the other locations, 362 where the input from riverine and terrestrial carbon sources is larger. The input from riverine 363 and terrestrial sources is indicated by more depleted $\delta^{13} \mathrm{C}$ values for SPM. Therefore, the 364 carbon sources available for the food web of Terneuzen will be more restricted. At the two 365 upstream locations, consumers might be feeding on more different carbon and nitrogen 366 sources. In this case, the stable isotope values may not be perfectly comparable with each 367 other among species, because of a difference in carbon and nitrogen sources and so, 368 biomagnification might also be more difficult to detect. For this reason, the influence of 369 trophic position on the bioaccumulation might be underestimated. This may explain why more 
370 significant relationships are found at the most downstream sampling location, Terneuzen, 371 where there are fewer carbon and nitrogen sources.

372

373 In conclusion, the contamination levels of POPs detected in the tissues of aquatic 374 species from the Scheldt estuary were relatively high compared to concentrations found in 375 other studies, making the Scheldt one of the most polluted estuaries in Europe. A decreasing 376 trend in POP levels towards the sea was observed. For POP concentrations in sediments, this 377 trend could be attributed to a dilution effect from mixing with seawater. However, 378 concentrations in biota more downstream were higher than expected after taking into account 379 the dilution effect, possibly due to differences in bioavailability. Regression of $\delta^{15} \mathrm{~N}$ results 380 with logged, lipid normalized concentration data showed more pronounced biomagnification 381 at the marine site, although the presence of multiple carbon sources at the freshwater side may 382 have led to an underestimation of the influence of the trophic level. 


\section{Acknowledgements}

385 The authors would like to thank VLIZ and INBO for their participation in the field

386 work. Particle size was measured in the lab of Ecosystem Management at the University of

387 Antwerp. Financial support for this research partially came from the Research Foundation

388 Flanders, FWO (1.5.182.13N). Krishna Das and Gilles Lepoint are research associates at the

389 F.R.S. - FNRS (Fonds National de la Reserche Scientifique, Belgium).

390

391 Supporting Information Available

392 The first paragraph in the Supporting Information gives a detailed description of the methods

393 and quality control used for POP analysis. Table SI-1 presents mean lipid content, weight and

394 total length of the collected species, together with median concentrations, separated per

395 location. Table SI-2 lists all significant correlations between tissue concentrations (ww) of

396 several POPs in the aquatic biota and their lipid content. Table SI-3 presents the mean $\delta^{13} \mathrm{C}$

397 and $\delta^{15} \mathrm{~N}$ values (\%o) of all samples per location. This information is available free of charge

398 via the Internet at http://pubs.acs.org/.

399 


\section{References}

401 1. Domingo, J. L.; Bocio, A., Levels of PCDD/PCDFs and PCBs in edible marine 402 species and human intake: A literature review. Environ. Int. 2007, 33, (3), 397-405.

403 2. Belpaire, C.; Goemans, G., Eels: contaminant cocktails pinpointing environmental 404 contamination. ICES J. Mar. Sci. 2007, 64, (7), 1423-1436.

405 3. Van Ael, E.; Covaci, A.; Blust, R.; Bervoets, L., Persistent organic pollutants in the 406 Scheldt estuary: Environmental distribution and bioaccumulation. Environ. Int. 2012, 407 408 409

5. Borga, K.; Fisk, A. T.; Hoekstra, P. F.; Muir, D. C. G., Biological and chemical factors 412

6. Fisk, A. T.; de Wit, C. A.; Wayland, M.; Kuzyk, Z. Z.; Burgess, N.; Robert, R.;

4. Coat, S.; Monti, D.; Legendre, P.; Bouchon, C.; Massat, F.; Lepoint, G., Organochlorine pollution in tropical rivers (Guadeloupe): Role of ecological factors in food web bioaccumulation. Environ. Pollut. 2011, 159, (6), 1692-1701.

420 of importance in the bioaccumulation and trophic transfer of persistent organochlorine contaminants in arctic marine food webs. Environ. Toxicol. Chem. 2004, 23, (10), 2367-2385. Braune, B.; Norstrom, R.; Blum, S. P.; Sandau, C.; Lie, E.; Larsen, H. J. S.; Skaare, J. U.; Muir, D. C. G., An assessment of the toxicological significance of anthropogenic contaminants in Canadian arctic wildlife. Sci. Total Environ. 2005, 351, 57-93.

7. Kullman, M. A.; Kidd, K. A.; Podemski, C. L.; Paterson, M. J.; Blanchfield, P. J., Assimilation of freshwater salmonid aquaculture waste by native aquatic biota. Can. J. Fish. Aquat. Sci. 2009, 66, (11), 1965-1975.

8. Coat, S.; Monti, D.; Bouchon, C.; Lepoint, G., Trophic relationships in a tropical stream food web assessed by stable isotope analysis. Freshwat. Biol. 2009, 54, (5), 1028-1041.

9. Verhaert, V.; Covaci, A.; Bouillon' S.; Abrantes, K.; Musibono, D.; Bervoets, L.; Verheyen, E.; Blust, R., Baseline levels and trophic transfer of persistent organic pollutants in sediments and biota from the Congo River Basin (DR Congo). Environ. Int. 2013, in press

10. Baeyens, W.; van Eck, B.; Lambert, C.; Wollast, R.; Goeyens, L., General description 430 of the Scheldt estuary. Hydrobiologia 1998, 366, 1-14. 
431 11. Baeyens, W.; Leermakers, M.; De Gieter, M.; Nguyen, H. L.; Parmentier, K.; Panutrakul, S.; Elskens, M., Overview of trace metal contamination in the Scheldt estuary and effect of regulatory measures. Hydrobiologia 2005, 540, 141-154.

12. Steen, R.; van der Vaart, J.; Hiep, M.; Van Hattum, B.; Cofino, W. P.; Brinkman, U. A. T., Gross fluxes and estuarine behaviour of pesticides in the Scheldt Estuary (19951997). Environ. Pollut. 2001, 115, (1), 65-79.

13. Wolff, W. J., The south-eastern North Sea: losses of vertebrate fauna during the past 2000 years. Biol. Conserv. 2000, 95, (2), 209-217.

14. Ysebaert, T.; Meininger, P. L.; Meire, P.; Devos, K.; Berrevoets, C. M.; Strucker, R. C. W.; Kuijken, E., Waterbird communities along the estuarine salinity gradient of the Schelde estuary, NW-Europe. Biodivers. Conserv. 2000, 9, (9), 1275-1296.

15. Heiri, O.; Lotter, A. F.; Lemcke, G., Loss on ignition as a method for estimating organic and carbonate content in sediments: reproducibility and comparability of results. J. Paleolimnol. 2001, 25, (1), 101-110.

16. Voorspoels, S.; Covaci, A.; Schepens, P., Polybrominated diphenyl ethers in marine species from the Belgian North Sea and the Western Scheidt Estuary: Levels, profiles, and distribution. Environ. Sci. Technol. 2003, 37, (19), 4348-4357.

17. Post, D. M., Using stable isotopes to estimate trophic position: Models, methods, and assumptions. Ecology 2002, 83, (3), 703-718.

18. Borga, K. K., K; Muir DCG.; Berglund O.; Conder JM.; Gobas FAPC.; Kucklick J.; Malm O.; Powell DE., Trophic magnification factors: Considerations of ecology, ecosystems and study design. Integr. Environ. Assess. Manage. 2011, 8, 64-84.

19. Jardine, T. D.; Kidd, K. A.; Fisk, A. T., Applications, considerations, and sources of uncertainty when using stable isotope analysis in ecotoxicology. Environ. Sci. Technol. 2006, 40, (24), 7501-7511.

20. McCutchan, J. H.; Lewis, W. M.; Kendall, C.; McGrath, C. C., Variation in trophic shift for stable isotope ratios of carbon, nitrogen, and sulfur. Oikos 2003, 102, (2), 378-390.

21. Ikemoto, T.; Tu, N. P. C.; Watanabe, M. X.; Okuda, N.; Omori, K.; Tanabe, S.; Tuyen, B. C.; Takeuchi, I., Analysis of biomagnification of persistent organic pollutants in the aquatic food web of the Mekong Delta, South Vietnam using stable carbon and nitrogen isotopes. Chemosphere 2008, 72, (1), 104-114. 
463

464

465

466

467

468

469

470

471

472

473

474

475

476

477

478

479

480

481

482

483

484

485

486

487

488

489

490

491

492

493

494

495

22. Bisi, T. L.; Lepoint, G.; Azevedo, A. D.; Dorneles, P. R.; Flache, L.; Das, K.; Malm, O.; Lailson-Brito, J., Trophic relationships and mercury biomagnification in Brazilian tropical coastal food webs. Ecol. Indicators 2012, 18, 291-302.

23. Commission, E., Commission Regulation (EU) No. 1259/2011 of 2 December 2011 amending Regulation (EC) No. 1881/2006 as regards maximum levels for dioxins, dioxin-like PCBs and non dioxin-like PCBs in foodstuffs. Official Journal of the European Union 2011, (L 320/18-23).

24. European Commision, 2011. Commission Regulation No 1259/2011 of 2 December 2011 amending Regulation (EC) No 1881/2006 as regards maximum levels for dioxins, dioxin-like PCBs and non dioxin-like PCBs in foodstuffs. L 320/18 Official Journal of the European Union 3.12.2011

25. Ferrante, M. C.; Clausi, M. T.; Meli, R.; Fusco, G.; Naccari, C.; Lucisano, A., Polychlorinated biphenyls and organochlorine pesticides in European eel (Anguilla anguilla) from the Garigliano River (Campania region, Italy). Chemosphere 2010, 78, (6), 709-716.

26. McHugh, B.; Poole, R.; Corcoran, J.; Anninou, P.; Boyle, B.; Joyce, E.; Foley, M. B.; McGovern, E., The occurrence of persistent chlorinated and brominated organic contaminants in the European eel (Anguilla anguilla) in Irish waters. Chemosphere 2010, 79, (3), 305-313.

27. Belpaire, C.; Geeraerts, C.; Roosens, L.; Neels, H.; Covaci, A., What can we learn from monitoring PCBs in the European eel? A Belgian experience. Environ. Int. 2011, $37,(2), 354-364$.

28. Bragigand, V.; Amiard-Triquet, C.; Parlier, E.; Boury, P.; Marchand, P.; El Hourch, M., Influence of biological and ecological factors on the bioaccumulation of polybrominated diphenyl ethers in aquatic food webs from French estuaries. Sci. Total Environ. 2006, 368, (2-3), 615-626.

29. Piskorska-Pliszczynska, J.; Maszewski, S.; Warenik-Bany, M.; Milkolajczyk, S.; Goraj, L., Survey of Persistent Organochlorine Contaminants (PCDD, PCDF, and PCB) in Fish Collected from the Polish Baltic Fishing Areas. Sci. World J. 2012.

30. Isosaari, P.; Hallikainen, A.; Kiviranta, H.; Vuorinen, P. J.; Parmanne, R.; Koistinen, J.; Vartiainen, T., Polychlorinated dibenzo-p-dioxins, dibenzofurans, biphenyls, naphthalenes and polybrominated diphenyl ethers in the edible fish caught from the Baltic Sea and lakes in Finland. Environ. Pollut. 2006, 141, (2), 213-225. 
496 31. Law, R. J.; Alaee, M.; Allchin, C. R.; Boon, J. P.; Lebeuf, M.; Lepom, P.; Stern, G. A., Levels and trends of polybrominated diphenylethers and other brominated flame retardants in wildlife. Environ. Int. 2003, 29, (6), 757-770.

32. Boon, J. P.; Lewis, W. E.; Tjoen-A-Choy, M. R.; Allchin, C. R.; Law, R. J.; de Boer, J.; ten Hallers-Tjabbes, C. C.; Zegers, B. N., Levels of polybrominated diphenyl ether (PBDE) flame retardants in animals representing different trophic levels of the North Sea food web. Environ. Sci. Technol. 2002, 36, (19), 4025-4032.

33. van Leeuwen, S. P. J.; de Boer, J., Brominated flame retardants in fish and shellfish levels and contribution of fish consumption to dietary exposure of Dutch citizens to HBCD. Mol. Nutr. Food Res. 2008, 52, (2), 194-203.

34. Manchester-Neesvig, J. B.; Valters, K.; Sonzogni, W. C., Comparison of polybrominated diphenyl ethers (PBDEs) and polychlorinated biphenyls (PCBs) in Lake Michigan salmonids. Environ. Sci. Technol. 2001, 35, (6), 1072-1077.

35. Hale, R. C.; La Guardia, M. J.; Harvey, E. P.; Mainor, T. M.; Duff, W. H.; Gaylor, M. O., Polybrominated diphenyl ether flame retardants in virginia freshwater fishes (USA). Environ. Sci. Technol. 2001, 35, (23), 4585-4591.

36. Gray, J. S., Biomagnification in marine systems: the perspective of an ecologist. Mar. Pollut. Bull. 2002, 45, (1-12), 46-52.

37. Voorspoels, S.; Covaci, A.; Maervoet, J.; De Meester, I.; Schepens, P., Levels and profiles of PCBs and OCPs in marine benthic species from the Belgian North Sea and the Western Scheldt Estuary. Mar. Pollut. Bull. 2004, 49, (5-6), 393-404.

38. Middelburg, J. J.; Nieuwenhuize, J., Carbon and nitrogen stable isotopes in suspended matter and sediments from the Schelde Estuary. Mar. Chem. 1998, 60, (3-4), 217-225.

39. Middelburg, J. J.; Herman, P. M. J., Organic matter processing in tidal estuaries. Mar. Chem. 2007, 106, (1-2), 127-147.

40. Peterson, B. J.; Fry, B., Stable isotopes in ecosystem studies. Annu. Rev. Ecol. Syst. 1987, 18, 293-320.

41. Ruus, A.; Ugland, K. I.; Skaare, J. U., Influence of trophic position on organochlorine concentrations and compositional patterns in a marine food web. Environ. Toxicol. Chem. 2002, 21, (11), 2356-2364.

42. Villa, S.; Bizzotto, E. C.; Vighi, M., Persistent organic pollutant in a fish community of a sub-alpine lake. Environ. Pollut. 2011, 159, (4), 932-939. 
528 43. Kidd, K. A.; Hesslein, R. H.; Ross, B. J.; Koczanski, K.; Stephens, G. R.; Muir, D. C. G., Bioaccumulation of organochlorines through a remote freshwater food web in the Canadian Arctic. Environ. Pollut. 1998, 102, (1), 91-103.

44. Wu, J. P.; Luo, X. J.; Zhang, Y.; Yu, M.; Chen, S. J.; Mai, B. X.; Yang, Z. Y., Biomagnification of polybrominated diphenyl ethers (PBDEs) and polychlorinated biphenyls in a highly contaminated freshwater food web from South China. Environ. Pollut. 2009, 157, (3), 904-909.

45. Bodin, N.; Le Loc'h, F.; Caisey, X.; Le Guellec, A. M.; Abarnou, A.; Loizeau, V.; Latrouite, D., Congener-specific accumulation and trophic transfer of polychlorinated biphenyls in spider crab food webs revealed by stable isotope analysis. Environ. Pollut. 2008, 151, (1), 252-261.

46. Fisk, A. T.; Hobson, K. A.; Norstrom, R. J., Influence of chemical and biological factors on trophic transfer of persistent organic pollutants in the northwater polynya marine food web. Environ. Sci. Technol. 2001, 35, (4), 732-738.

47. Houde, M.; Muir, D. C. G.; Kidd, K. A.; Guildford, S.; Drouillard, K.; Evans, M. S.; Wang, X.; Whittle, D. M.; Haffner, D.; Kling, H., Influence of lake characteristics on the biomagnification of persistent organic pollutants in lake trout food webs. Environ. Toxicol. Chem. 2008, 27, (10), 2169-2178.

48. Skarphedinsdottir, H.; Gunnarsson, K.; Gudmundsson, G. A.; Nfon, E., Bioaccumulation and Biomagnification of Organochlorines in a Marine Food Web at a Pristine Site in Iceland. Arch. Environ. Contam. Toxicol. 2010, 58, (3), 800-809.

49. Yu, Y.-X.; Zhang, S.-H.; Huang, N.-B.; Li, J.-L.; Pang, Y.-P.; Zhang, X.-Y.; Yu, Z.Q.; Xu, Z.-G., Polybrominated diphenyl ethers and polychlorinated biphenyls in freshwater fish from Taihu Lake, China: Their levels and the factors that influence biomagnification. Environ. Toxicol. Chem. 2012, 31, (3), 542-549.

50. Mizukawa, K.; Takada, H.; Takeuchi, I.; Ikemoto, T.; Omori, K.; Tsuchiya, K., Bioconcentration and biomagnification of polybrominated diphenyl ethers (PBDEs) through lower-trophic-level coastal marine food web. Mar. Pollut. Bull. 2009, 58, (8), 1217-1224.

51. Kelly, B. C.; Ikonomou, M. G.; Blair, J. D.; Gobas, F. A. P. C., Bioaccumulation behaviour of polybrominated diphenyl ethers (PBDEs) in a Canadian Arctic marine food web. Sci. Total Environ. 2008, 401, (1-3), 60-72.

52. De Laender, F.; Van Oevelen, D.; Middelburg, J. J.; Soetaert, K., Incorporating Ecological Data and Associated Uncertainty in Bioaccumulation Modeling: 
562 Methodology Development and Case Study. Environ. Sci. Technol. 2009, 43, (7), $563 \quad 2620-2626$.

564 53. Ruus, A.; Skaare, J. U.; Ingebrigtsen, K., Disposition and depuration of lindane 565 (gamma-HCH) and polychlorinated biphenyl-110 (2,3,3 ',4 ',6-pentachlorobiphenyl) in cod (Gadus morhua) and bullrout (Myoxocephalus scorpius) after single oral exposures. Environ. Toxicol. Chem. 2001, 20, (10), 2377-2382.

568

569

570 
571 Table 1. Median and range of POP concentrations in sediment (ng/g dw) and biota (ng/g ww; filamentous green algae expressed in

$572 \mathrm{ng} / \mathrm{g} \mathrm{dw}$ ) from the Scheldt estuary, together with lipid content (\%), number of measurements (N: individual measurements or pools for

573 POP analysis per sampling site, Terneuzen/Bath/Antwerpen) and the tissue analyzed. ICES PCBs are the 6 indicator PCBs: 28, 52,

$574101,138,153,180$. n.d. $=$ not detected.

\begin{tabular}{|c|c|c|c|c|c|c|c|c|c|c|c|c|c|c|c|c|c|c|c|c|c|c|c|c|c|}
\hline \multirow{3}{*}{$\begin{array}{l}\text { Sample } \\
\text { Sediment }\end{array}$} & & \multirow{3}{*}{$\begin{array}{c}\begin{array}{c}N \\
(T / B / A)\end{array} \\
2 / 2 / 2\end{array}$} & \multirow[t]{3}{*}{ Tissue } & \multicolumn{2}{|c|}{ Lipid (\%) } & \multicolumn{2}{|c|}{$\Sigma \mathrm{PCB}$} & \multicolumn{2}{|c|}{$\sum$ ICES PCB } & \multicolumn{2}{|c|}{ РCB 153} & \multicolumn{2}{|c|}{$\sum$ PBDE } & \multicolumn{2}{|c|}{ BDE47 } & \multicolumn{2}{|c|}{$\sum \mathrm{DDT}$} & \multicolumn{2}{|c|}{$p, p^{\prime}$-DDE } & \multicolumn{2}{|c|}{$\mathrm{HCB}$} & \multicolumn{2}{|c|}{$\sum \mathrm{HCH}$} & \multicolumn{2}{|c|}{$\sum$ chlordanes } \\
\hline & & & & & - & & 4,28 & & 1,58 & & 0,49 & & 56,8 & &, 02 & & 0,21 & &, 08 & & 0,02 & &, 35 & & n.d. \\
\hline & & & & & & $(1,75$ & $\begin{array}{l}-\quad 58,7) \\
\end{array}$ & $(0,43$ & - 21,5$)$ & $(0,08$ & - 4,62) & $(1,70$ & $-\quad 575)$ & $(0,02$ & $\begin{array}{l}-\quad 0,28) \\
\end{array}$ & $(0,15$ & - 4,45$)$ & $(0,05$ & $\begin{array}{l}-\quad 0,96) \\
\end{array}$ & $(0,02$ & - 0,19$)$ & $(0,10$ & $\begin{array}{l}-\quad 0,74) \\
\end{array}$ & & \\
\hline \multirow[t]{2}{*}{ Filamentous algae } & & \multirow[t]{2}{*}{$1 / 1 / 1$} & & \multirow{2}{*}{\multicolumn{2}{|c|}{ - }} & \multicolumn{2}{|r|}{32,7} & \multicolumn{2}{|r|}{9,60} & \multicolumn{2}{|c|}{2,30} & \multicolumn{2}{|c|}{0,96} & \multicolumn{2}{|c|}{0,47} & \multicolumn{2}{|c|}{2,51} & \multicolumn{2}{|c|}{1,22} & \multicolumn{2}{|c|}{0,13} & \multicolumn{2}{|c|}{1,05} & & 0,13 \\
\hline & & & & & & $(2,52$ & - 32,7$)$ & $(0,47$ & $-10,8)$ & $(0,07$ & - 2,75$)$ & $(0,41$ & $-1,52)$ & $(0,19$ & - 0,59$)$ & $(0,30$ & $-2,83)$ & $(0,17$ & $-1,53)$ & $(0,07$ & $-0,22)$ & $(0,83$ & - 1,64$)$ & $(0,07$ & - 0,15$)$ \\
\hline Mollusks & & & & & & & & & & & & & & & & & & & & & & & & & \\
\hline Mytilus edulis & Blue mussel & $4 / 0 / 0$ & whole & & 2,51 & & 94,9 & & 41,1 & & 18,1 & &, 59 & &, 21 & & 3,75 & & .40 & & 0,03 & &, 22 & & 0,23 \\
\hline & & & & $(2,20$ & - 2,97$)$ & $(79,5$ & $-111)$ & $(34,5$ & - 48,2$)$ & $(15,2$ & - 21,3$)$ & $(0,49$ & - 1,06$)$ & $(0,17$ & - 0,29$)$ & $(3,02$ & - 4,81$)$ & $(1,90$ & - 3,04$)$ & $(0,03$ & - 0,13$)$ & $(0,17$ & $0,24)$ & $(0,19$ & - 0,27$)$ \\
\hline Macoma balthica & Baltic tellin & $0 / 2 / 0$ & whole & & 2,80 & & 249 & & 103 & & 37,2 & & 1,71 & &, 60 & & 11,2 & & ,03 & & 0,24 & &, 38 & & 0,87 \\
\hline & & & & $(2,73$ & $-\quad 2,86)$ & $(245$ & $-253)$ & (101 & $-105)$ & $(36,5$ & - 37,8$)$ & $(1,62$ & $-1,80)$ & $(0,55$ & $-0,65)$ & $(10,8$ & - 11,7) & $(6,72$ & - 7,35$)$ & $(0,24$ & - 0,24$)$ & $(0,33$ & - 0,44$)$ & $(0,84$ & - 0,90$)$ \\
\hline Littorina littorea & $\begin{array}{l}\text { Common } \\
\text { periwinkle }\end{array}$ & $4 / 0 / 0$ & whole & & 0,82 & & 22,8 & & 10,4 & & 3,97 & & 0,01 & & ר.d. & & 0,70 & &, 59 & & 0,03 & &, 16 & & n.d. \\
\hline Polychaeta & & & & $(0,69$ & - 1,06$)$ & $(17,6$ & - 28,0$)$ & $(7,84$ & - 12,5$)$ & $(3,19$ & - 4,87$)$ & $(0,01$ & - 0,05$)$ & & & $(0,60$ & - 0,82$)$ & $(0,49$ & - 0,67$)$ & $(0,03$ & - 0,10$)$ & $(0,10$ & - 0,19$)$ & & \\
\hline Nereis diversicolor & Ragworm & $0 / 2 / 3$ & whole & & 1,34 & & 93,8 & & 42,7 & & 18,2 & & 0,86 & &, 31 & & 4,74 & & ,78 & & 0,17 & &, 40 & & 0,54 \\
\hline & & & & $(1,05$ & - 1,65) & $(50,6$ & - 142) & $(22,9$ & - 65,7$)$ & $(9,34$ & - $\quad 30,4)$ & $(0,46$ & - 1,71$)$ & $(0,15$ & - 0,62$)$ & $(2,59$ & - 9,37$)$ & $(1,50$ & - 5,13$)$ & $(0,10$ & - 0,34$)$ & $(0,10$ & $0,90)$ & $(0,21$ & - 1,14$)$ \\
\hline Arenicola marina & Lugworm & $3 / 0 / 0$ & whole & & 1,00 & & 22,4 & & 9,60 & & 4,02 & & 0,24 & &, 04 & & 0,85 & &, 58 & & n.d. & &, 10 & & n.d. \\
\hline & & & & $(0,99$ & $-\quad 1,02)$ & $(18,1$ & - $\quad 30,3)$ & $(7,99$ & - 13,3$)$ & $(3,17$ & - 5,38$)$ & $(0,20$ & - 0,35$)$ & $(0,04$ & - 0,07$)$ & $(0,80$ & - 0,90$)$ & $(0,55$ & - 0,62$)$ & & & $(0,10$ & - 0,36$)$ & & \\
\hline Crustacea & & & & & & & & & & & & & & & & & & & & & & & & & \\
\hline $\begin{array}{l}\text { Chaetogammarus } \\
\text { marinus }\end{array}$ & & $1 / 1 / 0$ & whole & & 1,29 & & 33,6 & & 15,2 & & 5,20 & & 0,26 & &, 15 & & 0,69 & &, 40 & & n.d. & & 02 & & n.d. \\
\hline & & & & $(1,10$ & - 1,47$)$ & $(33,5$ & - 33,7$)$ & $(14,4$ & - 16,0$)$ & $(5,17$ & - 5,24$)$ & $(0,13$ & - 0,39$)$ & $(0,10$ & - 0,20$)$ & $(0,39$ & - 0,98$)$ & $(0,29$ & - 0,50$)$ & & & $(0,75$ & - 3,28$)$ & & \\
\hline Crangon crangon & Brown shrimp & $2 / 4 / 0$ & muscle & & 0,84 & & 25,3 & & 10,7 & & 3,95 & & 0,01 & &, 01 & & 0,56 & &, 56 & & n.d. & &, 03 & & n.d. \\
\hline
\end{tabular}




\begin{tabular}{|c|c|c|c|c|c|c|c|c|c|c|c|c|c|c|c|c|c|c|c|c|c|c|c|c|c|}
\hline \multirow[t]{2}{*}{ Sample } & & \multirow[t]{2}{*}{$\underset{(T / B / A)}{N}$} & \multirow[t]{2}{*}{ Tissue } & \multicolumn{2}{|c|}{ Lipid (\%) } & \multicolumn{2}{|c|}{$\sum \mathrm{PCB}$} & \multicolumn{2}{|c|}{ ¿ICES PCB } & \multicolumn{2}{|c|}{ РCB 153} & \multicolumn{2}{|c|}{$\sum$ PBDE } & \multicolumn{2}{|c|}{ BDE47 } & \multicolumn{2}{|c|}{$\sum \mathrm{DDT}$} & \multicolumn{2}{|c|}{$p, p^{\prime}-\mathrm{DDE}$} & \multicolumn{2}{|c|}{$\mathrm{HCB}$} & \multicolumn{2}{|c|}{$\sum \mathrm{HCH}$} & \multicolumn{2}{|c|}{$\sum$ chlordanes } \\
\hline & & & & $(0,77$ & - 1,08$)$ & $(17,8$ & - 61,9$)$ & $(7,68$ & - 28,4$)$ & $(2,78$ & $-11,3)$ & $(0,01$ & - 0,06$)$ & $(0,01$ & $-0,06)$ & $(0,40$ & - 0,86$)$ & $(0,40$ & - 0,86$)$ & & & $(0,03$ & - 0,25$)$ & & \\
\hline \multirow[t]{2}{*}{ Carcinus maenas } & Shore crab & $2 / 11 / 0$ & muscle & \multicolumn{2}{|c|}{0,63} & \multicolumn{2}{|c|}{84,1} & \multicolumn{2}{|c|}{41,5} & \multicolumn{2}{|c|}{20,3} & \multicolumn{2}{|c|}{0,22} & \multicolumn{2}{|c|}{0,15} & \multicolumn{2}{|c|}{1,50} & \multicolumn{2}{|c|}{1,46} & \multicolumn{2}{|c|}{0,06} & \multicolumn{2}{|c|}{0,06} & & n.d. \\
\hline & & & & $(0,51$ & - 0,88$)$ & $(30,4$ & $-125)$ & $(16,8$ & - 63,4$)$ & $(8,43$ & - 28,9$)$ & $(0,11$ & - 0,51$)$ & $(0,05$ & $-0,35)$ & $(0,51$ & - 2,29) & $(0,47$ & - 2,01$)$ & $(0,06$ & - 0,26$)$ & $(0,06$ & $-0,45)$ & & \\
\hline Eriocheir sinensis & $\begin{array}{l}\text { Chinese } \\
\text { mitten crab }\end{array}$ & $0 / 3 / 4$ & muscle & & 0,61 & & 80,5 & & 43,2 & & 18,6 & & 1,22 & & 0,84 & & 2,39 & & 2,35 & & 0,19 & & 0,06 & & 1,23 \\
\hline & & & & $(0,39$ & - 0,97$)$ & $(40,5$ & $-336)$ & $(22,0$ & - 187) & $(8,18$ & - 69,6$)$ & $(0,82$ & - 4,55$)$ & $(0,51$ & - 3,64$)$ & $(1,52$ & - 7,07$)$ & $(1,48$ & - 7,03$)$ & $(0,06$ & - 0,73$)$ & $(0,06$ & - 0,34$)$ & $(0,27$ & - 2,47$)$ \\
\hline Fish & & & & & & & & & & & & & & & & & & & & & & & & & \\
\hline Platichthys flesus & $\begin{array}{l}\text { European } \\
\text { flounder }\end{array}$ & $5 / 5 / 6$ & muscle & & 0,72 & & 90,4 & & 42,5 & & 16,2 & & 0,60 & &, 40 & & 2,23 & & 1,72 & & 0,10 & & , 05 & & 0,08 \\
\hline & & & & $(0,44$ & - 1,89$)$ & $(34,0$ & - 344$)$ & $(15,7$ & - 155) & $(6,29$ & - 65,8$)$ & $(0,19$ & - 3,32$)$ & $(0,09$ & - 2,17$)$ & $(1,14$ & - 11,9$)$ & $(0,81$ & - 8,43$)$ & $(0,06$ & - 0,49$)$ & $(0,05$ & - 0,39$)$ & $(0,08$ & - 0,60$)$ \\
\hline Solea solea & Common sole & $1 / 4 / 6$ & muscle & & 0,60 & & 47,7 & & 22,2 & & 8,07 & & 0,18 & & 0,06 & & 1,26 & & 0,90 & & n.d. & & 0,05 & & n.d. \\
\hline & & & & $(0,45$ & $-1,02)$ & $(29,3$ & - 107) & $(13,7$ & - 51,8$)$ & $(4,79$ & - 20,2$)$ & $(0,13$ & - 0,51$)$ & $(0,04$ & $-0,18)$ & $(0,58$ & - 3,66$)$ & $(0,38$ & $-2,65)$ & & & $(0,05$ & $-0,13)$ & & \\
\hline Osmerus eperlanus & Smelt & $2 / 7 / 0$ & muscle & & 1,19 & & 76,1 & & 37,1 & & 14,1 & & 0,67 & & 0,45 & & 3,05 & & 2,16 & & 0,21 & & 0,05 & & 0,08 \\
\hline & & & & $(0,92$ & - 1,74) & $(41,9$ & $-235)$ & $(18,6$ & $-105)$ & $(7,44$ & - 44,3$)$ & $(0,31$ & - 1,64) & $(0,19$ & - 1,05$)$ & $(1,84$ & - 11,4) & $(1,27$ & - 7,77$)$ & $(0,13$ & - 0,44$)$ & $(0,05$ & $-0,12)$ & $(0,08$ & - 0,41$)$ \\
\hline Sprattus sprattus & $\begin{array}{l}\text { European } \\
\text { sprat }\end{array}$ & $0 / 1 / 0$ & muscle & & 0,96 & & 210 & & 102 & & 48,0 & & 1,00 & & , 55 & & 8,47 & & 7,34 & & 0,12 & & 0,17 & & n.d. \\
\hline Sander lucioperca & Pike-perch & $0 / 2 / 3$ & & & 0,53 & & 140 & & 65,4 & & 25,8 & & 1,32 & & 0,76 & & 5,02 & & 3,86 & & 0,15 & & 0,15 & & 0,08 \\
\hline & & & & $(0,49$ & $-1,00)$ & $(96,2$ & $-290)$ & $(45,6$ & - 137) & $(18,2$ & - 55,4$)$ & $(0,64$ & - 4,69) & $(0,35$ & $-1,96)$ & $(3,19$ & - 8,62) & $(2,51$ & - 7,06$)$ & $(0,06$ & - 0,21$)$ & $(0,05$ & - 0,74$)$ & $(0,08$ & $-0,16)$ \\
\hline Trisopterus luscus & Pouting & $3 / 4 / 0$ & muscle & & 0,66 & & 24,5 & & 11,3 & & 4,46 & & 0,14 & & 0,05 & & 0,84 & & 0,64 & & 0,06 & &, 05 & & 0,08 \\
\hline & & & & $(0,28$ & $-\quad 0,76)$ & $(9,5$ & $-48,9)$ & $(3,88$ & $-\quad 22,2)$ & $(1,71$ & - 9,03) & $(0,13$ & - 0,17$)$ & $(0,04$ & $-0,08)$ & $(0,55$ & $-1,15)$ & $(0,38$ & $-\quad 0,88)$ & $(0,06$ & $-0,18)$ & $(0,05$ & $-0,13)$ & $(0,08$ & $-0,17)$ \\
\hline $\begin{array}{l}\text { Myoxocephalus } \\
\text { scorpius }\end{array}$ & $\begin{array}{l}\text { Shorthorn } \\
\text { sculpin }\end{array}$ & $2 / 6 / 0$ & muscle & & 0,83 & & 30,1 & & 18,8 & & 8,68 & & 0,22 & & 0,13 & & 0,95 & & 0,79 & & 0,06 & & 0,05 & & n.d. \\
\hline & & & & $(0,63$ & $-\quad 1,14)$ & $(12,1$ & $-43,4)$ & $(6,59$ & - 25,9) & $(3,02$ & - 12,3$)$ & $(0,13$ & - 0,31$)$ & $(0,04$ & $-0,22)$ & $(0,57$ & $-1,58)$ & $(0,41$ & $-\quad 1,42)$ & $(0,06$ & - 0,15$)$ & $(0,05$ & $-0,14)$ & & \\
\hline Anguilla anguilla & European eel & $0 / 0 / 6$ & muscle & & 18,6 & & 1290 & & 645 & & 285 & & 8,76 & & 5,85 & & 49,3 & & 32,3 & & 3,92 & & 2,24 & & 5,67 \\
\hline & & & & $(9,16$ & - 23,2$)$ & $(846$ & - 2193) & $(433$ & - 1102) & (191 & - 512) & $(7,52$ & $-18,1)$ & $(4,40$ & - 11,0$)$ & $(36,8$ & - 89,3) & $(28,2$ & - 60,4$)$ & $(2,10$ & - 5,67$)$ & $(1,06$ & - $\quad 3,74)$ & $(3,29$ & - 7,14$)$ \\
\hline
\end{tabular}


576 Table 2. Statistics for the significant linear regression between log-transformed POP

577 concentrations and $\delta^{15} \mathrm{~N}$ values, together with the corresponding TMFs.

\begin{tabular}{llcccc}
\hline Location & Compound & $\mathrm{p}$ & $\mathrm{r}^{2}$ & Slope & TMF \\
\hline Terneuzen, L1 & PCB 118 & 0.016 & 0.190 & 0.061 & 1.15 \\
$\mathrm{~N}=30$ & PCB 153 & 0.018 & 0.184 & 0.065 & 1.16 \\
& PCB 138 & 0.042 & 0.139 & 0.057 & 1.14 \\
& PCB 128 & 0.049 & 0.131 & 0.056 & 1.14 \\
& PCB 156 & 0.004 & 0.259 & 0.081 & 1.21 \\
& PCB 183 & 0.043 & 0.138 & 0.058 & 1.14 \\
& PCB 180 & $<0.001$ & 0.423 & 0.110 & 1.29 \\
& PCB 170 & $<0.001$ & 0.450 & 0.126 & 1.34 \\
& PCB 199 & 0.034 & 0.205 & 0.120 & 1.32 \\
& PCB 194 & 0.001 & 0.416 & 0.203 & 1.60 \\
& $p, p^{\prime}-$ DDE & 0.023 & 0.171 & 0.068 & 1.17 \\
\hline Bath, L2 & $\square-$ HCH & 0.001 & 0.371 & -0.191 & 0.64 \\
$\mathrm{~N}=52$ & $p, p^{\prime}-$ DDD & 0.016 & 0.110 & 0.105 & 1.27 \\
\hline Only resuts & PBDE 100 & 0.013 & 0.129 & 0.068 & 1.17 \\
\hline
\end{tabular}

578 Only results with $\mathrm{r}^{2}>0.1$ are shown.

579 

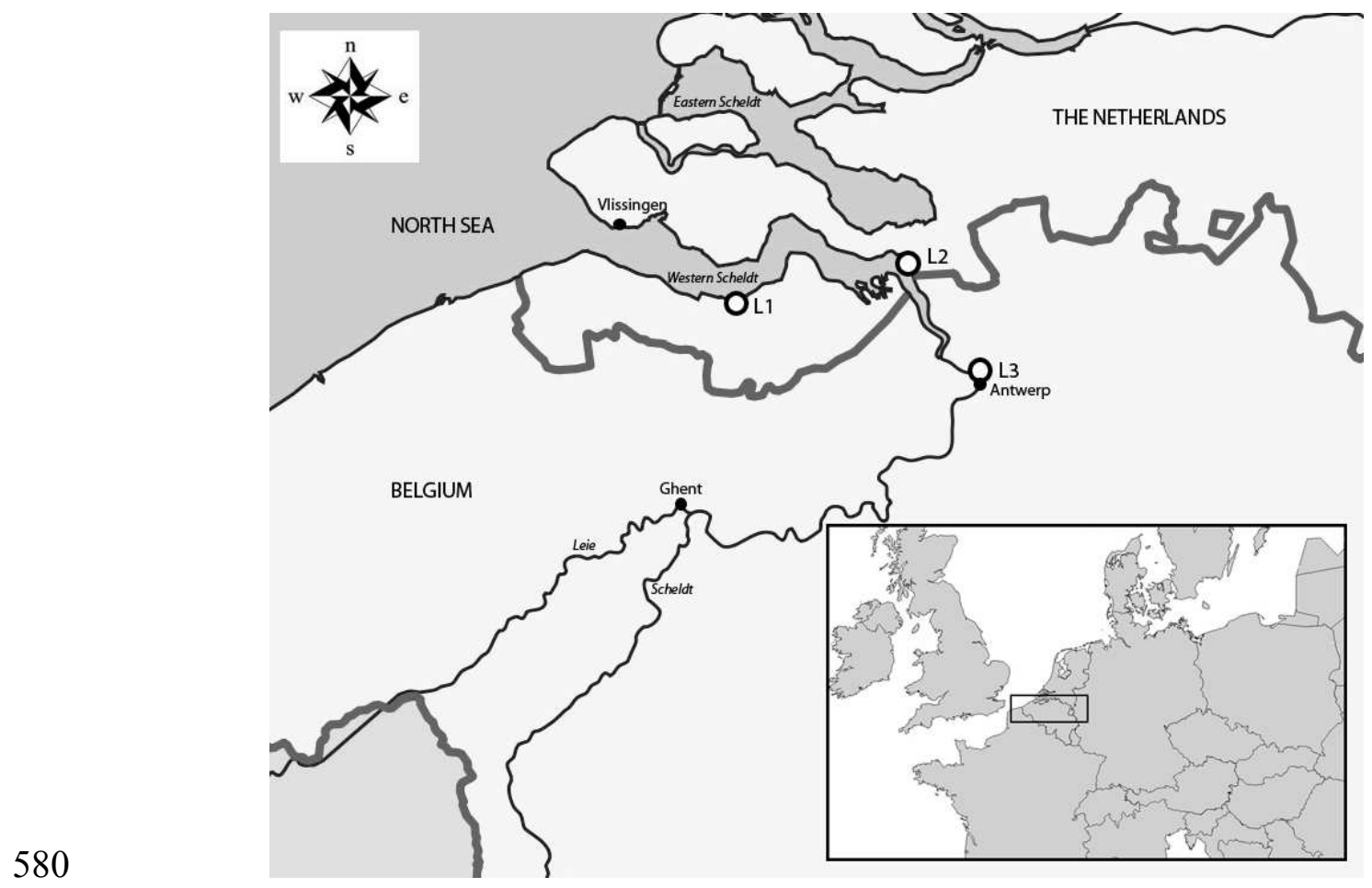

581 Fig. 1. Sampling locations along the Scheldt estuary: 1-Terneuzen; 2-Bath (the

582 Netherlands); 3-Antwerpen (Belgium) 

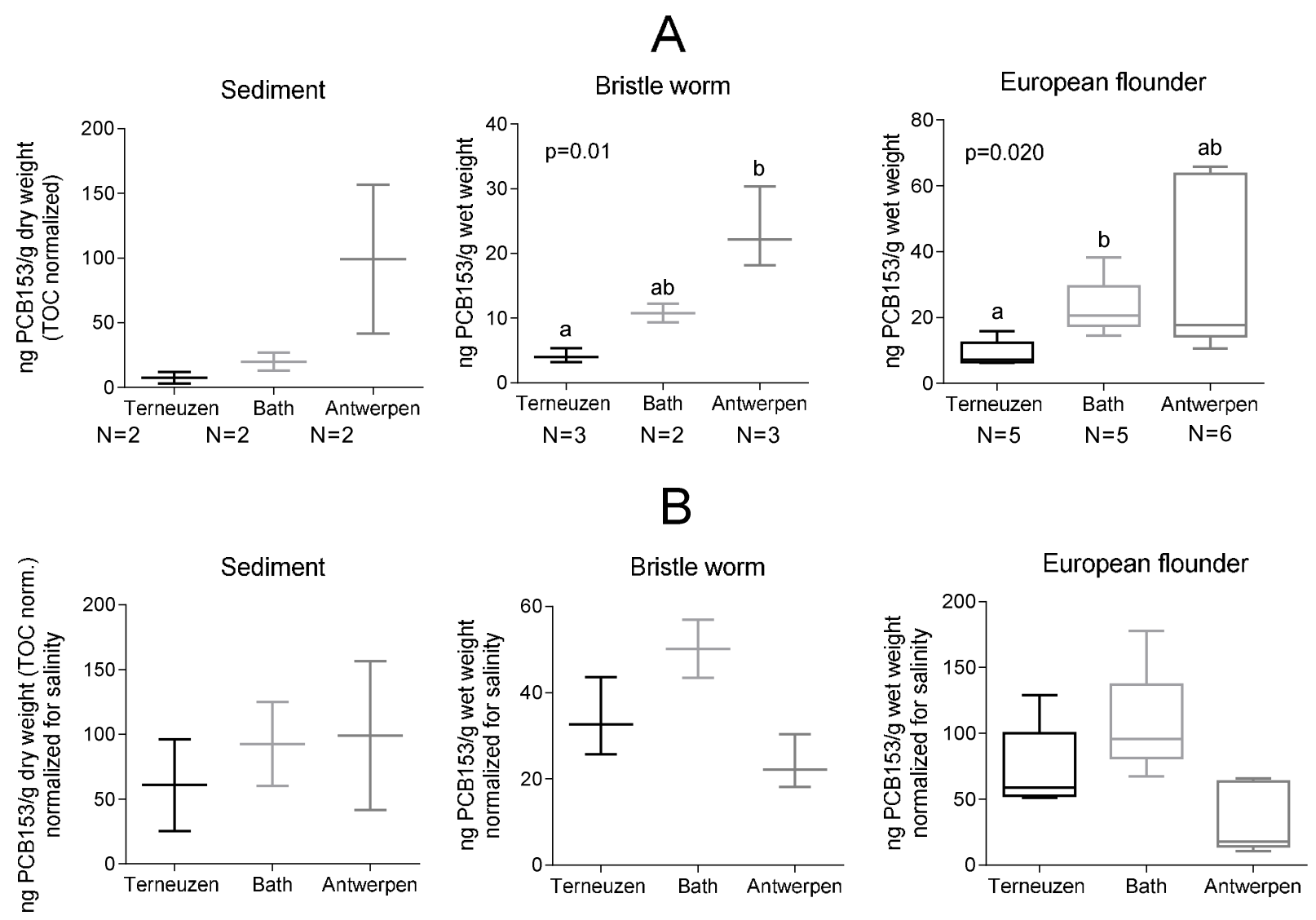

583

584 Fig. 2. Boxplots of CB153 concentrations in sediment (TOC normalized), bristle worm

585 and European flounder, A) before and B) after normalization for the ratio of salinity at

586 (Site X/Antwerpen). Salinity values used: Terneuzen, 27.3; Bath, 15.6; Antwerpen, 3.4.

587 Ratios used: (Terneuzen/Antwerpen) = 8.1; (Bath/Antwerpen) = 4.7;

588 (Antwerpen/Antwerpen $)=1$. Salinity values are year averages from a monitoring

589 database from Rijkswaterstaat, a part of the Dutch Ministry of Infrastructure and the

590 Environment, and from the Flemish Environment Agency (VMM). The relations between

591 POP concentrations in sediment and biota from the same locations, with taking into

592 account sediment characterstics (TOC and grain size) were studied in Van Ael et al.,

$5932012^{3}$. 

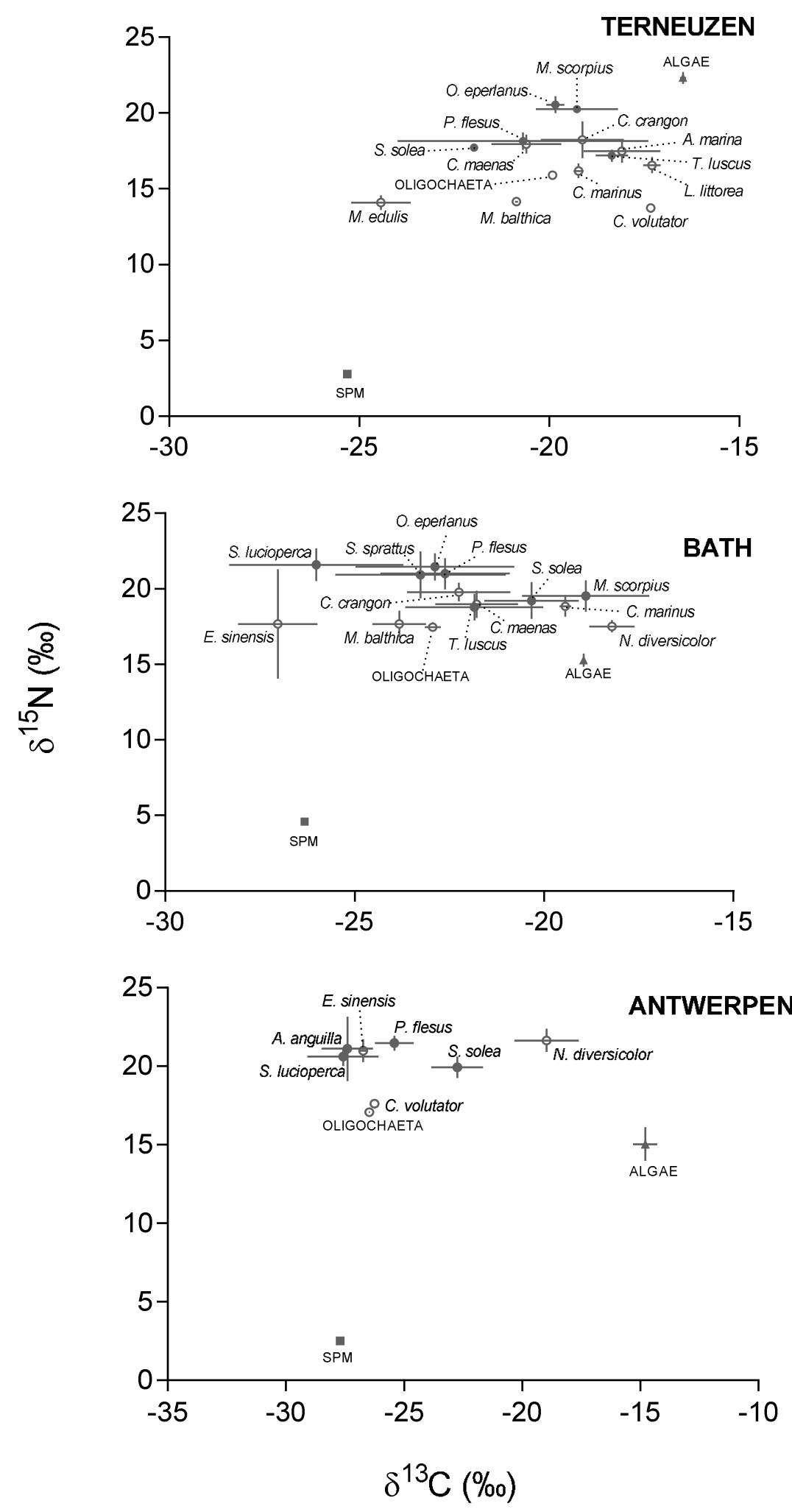

596 Fig. 3. Stable isotope signature (mean \pm SD) for all samples at the three sampling 597 locations, with $\delta^{15} \mathrm{~N}$ indicating the trophic level of the organisms. Symbols: $\bullet$ fish, $\circ$

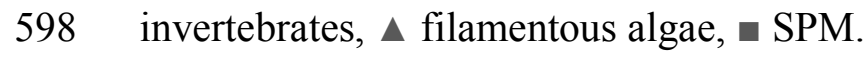



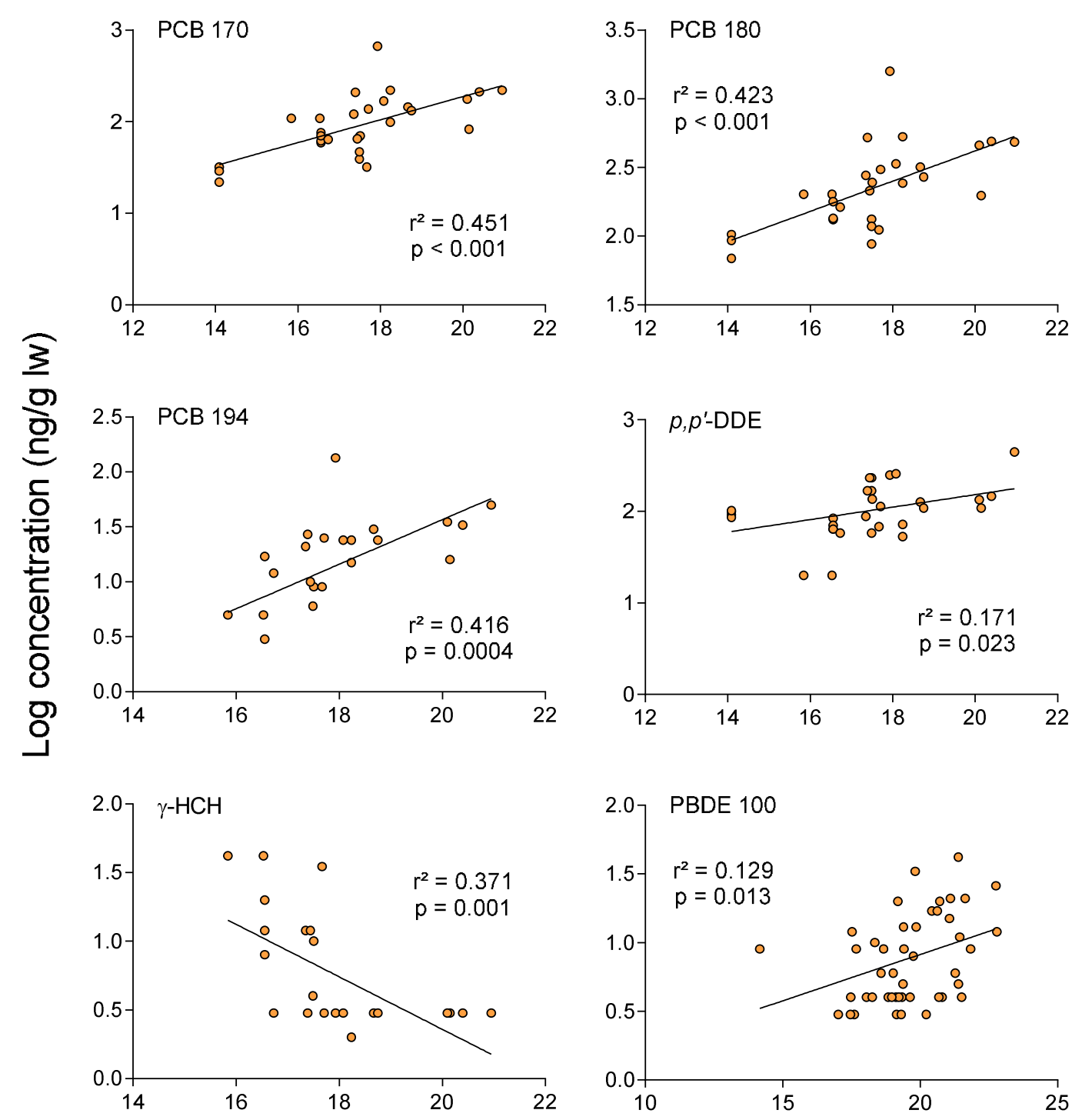

600

$\delta^{15} \mathrm{~N}(\%)$

601 Fig. 4. Linear regression between log-transformed POP concentrations (ng/g lw) and $\delta^{15} \mathrm{~N}$

602 values from biota samples from Terneuzen $(\mathrm{N}=30)$ and Bath (PBDE 100; $\mathrm{N}=52$ ).

603

604 


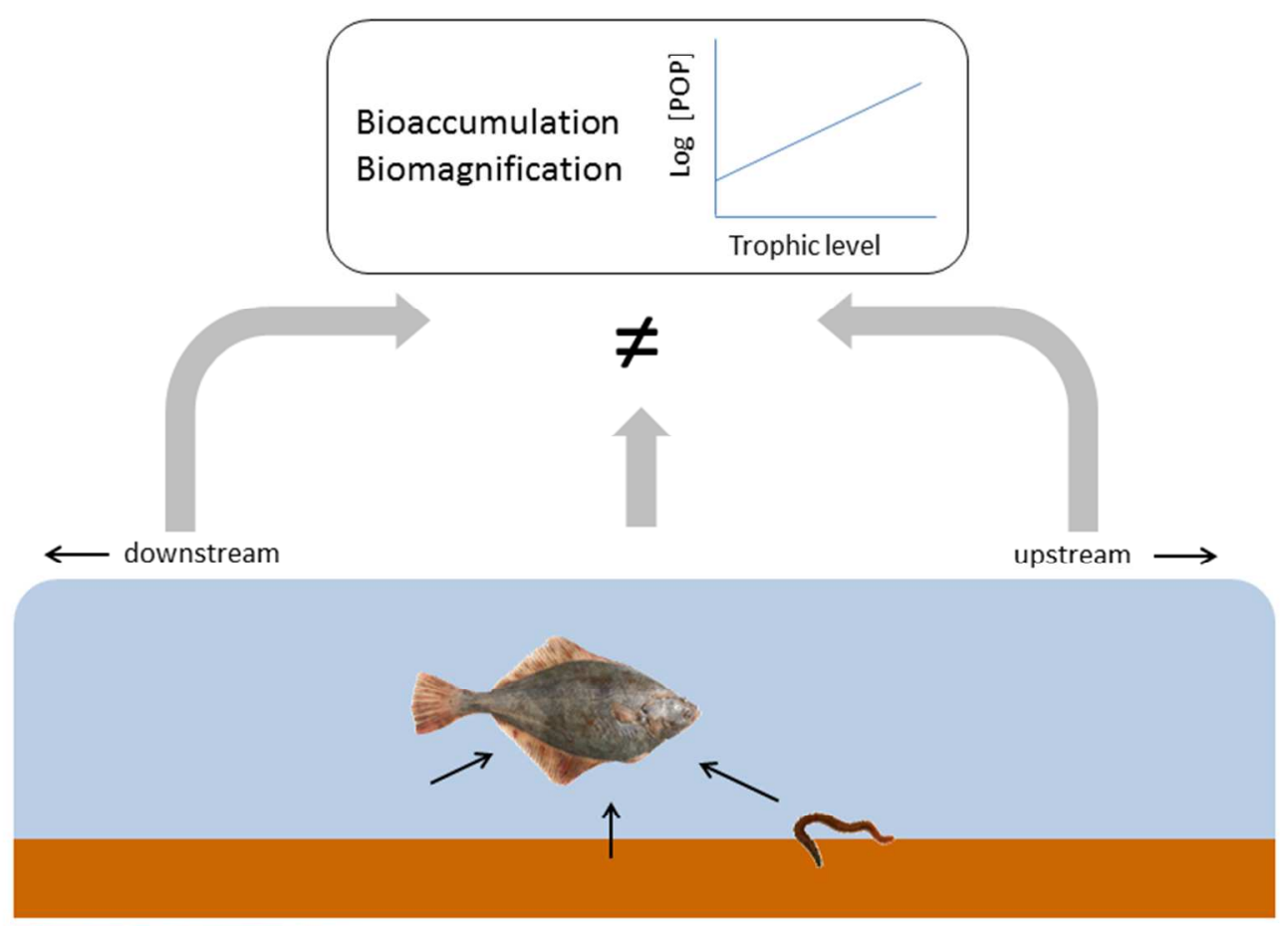

Salinity

Contaminants

605 